\title{
GREAT TITS', Parus major (PASSERIFORMES, TURDIDAE), DIET IN TRANSFORMED FOREST ECOSYSTEMS OF NORTHEASTERN UKRAINE
}

\author{
DIANA YUZYK $\otimes^{1}$, ANGELA CHAPLYHINA ${ }^{2}$ \\ ${ }^{1}$ National Park 'Cheremoskyi', Fedkovicha st., 35, Putila urban village, Chernivtsi Region, 59100, Ukraine; e-mail: muscicapa@ukr.net \\ ${ }^{2}$ H. S. Skovoroda Kharkiv National Pedagogical University, Alchevskykh st., 29, Kharkiv, 61002, Ukraine; e-mail: iturdus@ukr.net \\ $\triangle$ Corresponding author
}

Received: 11 September 2020 / Accepted: 13 February 2021

Abstract

Yuzyk D., Chaplyhina A.: Great tits', Parus major (Passeriformes, Turdidae), diet in transformed forest ecosystems of northeastern Ukraine. Ekológia (Bratislava), Vol. 40, No. 4, p. 392-400, 2021.

\begin{abstract}
The diet spectrum of the great tit (Parus major L., 1758) was studied in transformed forests of northeastern Ukraine. Four forest ecosystems were surveyed: four model sites in oak woodlands and in a pine-oak forest with different stages of recreational digression. Forty-seven taxa of invertebrates $(\mathrm{n}=325)$ were detected in the ration of great tit chicks. Insecta $(72.4 \%)$ : Lepidoptera (seven families, 35.9\%), Hymenoptera (two families, $21.0 \%)$, Diptera (seven families, $2.7 \%$ ) and Coleoptera (four families, $1.8 \%$ ) were among them. In terms of the qualitative composition of invertebrates (20 species, $42.6 \%$ ) and the proportion of seized food objects ( 159 objects), phytophages prevailed. The food composition of great tit chicks was the most similar in territories MS1 and MS4. It contained six common taxa for these territories (Stugren-Radulescu Index $=0.7$, Jaccard $=0.2$, Sorensen $=0.3$ )
\end{abstract}

Key words: diet, zoophages, phytophages, saprophages, necrophages, mixophages.

\section{Introduction}

The diet of some species of passerines is poorly studied, geographical coverage is extremely uneven $(70 \%$ of data are from Germany, Russia, Slovakia, the Czech Republic, Poland and the $\mathrm{UK}$ ), and most studies are not representative (three seasons, ${ }^{3} 20$ broods per season), which puts their validity into doubt. Most of the studies (Cholewa, Wesolowski, 2011) were carried out several decades ago under different conditions and, most likely, they cannot be regarded as representative for our region of research.

Trophic features of the species are decisive in the management and conservation of bird species diversity in both natural and transformed areas (Korňan, Adamík, 2017). Support of biodiversity requires understanding of the role of trophic interactions and the potential effects caused by the loss of certain links (Teichman et al., 2013). In such cases, downward trophic cascades occur (Bridgeland et al., 2010). Food chains form a network of trophic interactions, and study of their functioning is important for elucidating the processes and functions of ecosystems. Thus, direct links between predator and prey are mediated by numerous environmental and evolutionary determinants (Kuwae et al., 2012). Trophic interactions of species are structured on a wide spatial scale according to their functional characteristics (Brooks et al., 2012).

Lepidoptera larvae are known to be the most important component of great tit chicks' diet (Barba, Gildelgado, 1990). They also predominate in the diet of blackbird chicks (Turdus merula)
(Chaplygina, Pakhomov, 2020). Adult tits in broods with a greater number of chicks concentrate on more accessible food objects (Tortricids); in broods with a smaller number of chicks, the percentage of other preys (Noctuids) in the diet increases (GarciaNavas, Sanz, 2010).

Insectivorous birds should adjust the hatching of chicks to a short period of availability of food (appearance of lepidopteran larvae) for feeding (Garcia-Navas, Sanz, 2011). Breeding of blue tit chicks (Cyanistes caeruleus) is usually timed to the period when caterpillars are the most common (Banbura et al., 1999).

Not far from Krakow (Poland), differences in the diet of great and blue tit chicks in two European forests were clarified and it was checked whether the ecological niches of the two species overlap. It was found that both species of birds occupied different territories in each forest, but the diet of chicks contained similar species of invertebrates (Grzędzicka, 2018). However, studies confirmed that blue tit chicks better swallow caterpillars (they need less time); they swallow spiders and grasshoppers somewhat longer due to the mechanical constraints that prevent them from swallowing very large objects, which affects the choice of the prey. Relatively, with the great tit, such restrictions may be less stringent due to the larger size of its body (Banbura et al., 1999).

The diet and frequency of great tit chicks' feeding was studied using electronic chronographs and cameras in artificial nests in Corsica and on the mainland. In addition to caterpillars, a much

(C) The Author(s) 2021. This is an open access article distributed under the terms of the CC BY-NC-ND license.

https://content.sciendo.com/view/journals/eko/eko-overview.xml 


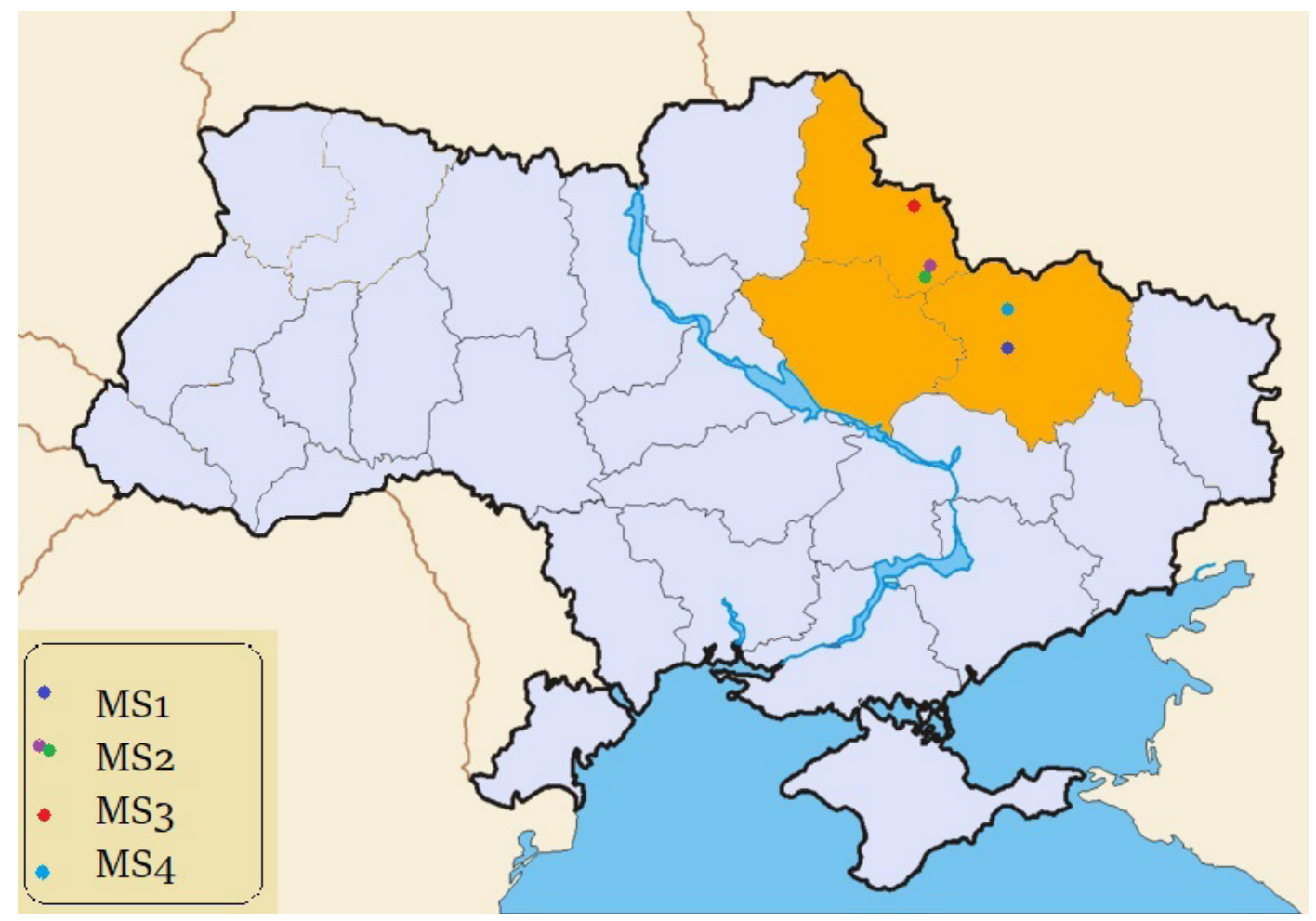

Fig. 1. Map of model sites.

wider range of taxa was represented in the diet (Blondel et al. 1991).

The presence of appropriate feeding stations in the biotope is important for maintaining of bird populations. In Europe, there is the practice of arranging special canteen bird feeders during the reproductive period (Amrhein, 2013).

In the park area, great tits, blue tits and robins (Erithacus rubecula) prefer to visit feeding places with high-calorie and protein-rich food (peanuts, cheese), but some birds choose bread that is more carbohydrate rich (Støstad, 2017).

In the Czech Republic, the trophic dependence of birds on invasive plant species is considered (Hanzelka, Reif, 2015). In the conditions of the transformed forest ecosystems of the northeast of Ukraine, special studies of the ration of great tit chicks have not been conducted, highlighting the need for carefully studying the food spectrum of this species as the main factor influencing the number of birds.

\section{Material and methods}

Field materials were collected from the third decade of March to the first decade of July 2013-2016 from the city of Kharkiv (Zhuravlivs'kyy Hydropark, a Lisopark), Kharkiv Region (the National Park 'Homilshanski Lisy') and Sumy Region (the site 'Vakalivshchyna', the National Park 'Hetmanskyi': villages Klymentove and Kam'yanka) (Fig. 1). According to Gensiruk's classification (2002), three model sites, selected in the oak forests, were characterised by different stages of recreational digression. The model sites in the National Park Hetmanskyi and Zhuravlivs'kyy Hydropark were located in a pine-oak forest.
Table 1. Number of field materials of the great tits in model sites.

\begin{tabular}{|l|c|c|c|c|}
\hline Site & $\begin{array}{c}\text { Number } \\
\text { of nestlings }\end{array}$ & $\begin{array}{c}\text { Number } \\
\text { of nests }\end{array}$ & $\begin{array}{c}\text { Number } \\
\text { of food pellets }\end{array}$ & $\begin{array}{c}\text { Number } \\
\text { of food items }\end{array}$ \\
\hline MS1 & 132 & 26 & 94 & 91 \\
\hline MS2 & 133 & 26 & 94 & 140 \\
\hline MS3 & 57 & 11 & 40 & 69 \\
\hline MS4 & 62 & 12 & 43 & 25 \\
\hline Total & 384 & 75 & 271 & 325 \\
\hline
\end{tabular}

Model site 1 (MS1) is located within a recreational zone of the National Park Homilshanski Lisy in the vicinities of the study plots of H. S. Skovoroda Kharkiv National Pedagogical University and Karazin Kharkiv National University. In terms of the level of anthropogenic load, biocenotic conditions in this area were heterogeneous, which characterised it as a territory with an average level of transformation. These areas are exposed to intensive recreation pressure during the bird breeding season. The wood includes damaged and diseased trees (about 35\%); the crown closure is about $70 \%$. The understory and shrub layer are available, but poorly differentiated. The grassy layer is partly disturbed; the projective cover reaches $85 \%$ in some areas. The forest floor is of little disturbance. Forest paths occupy up to $30 \%$ of the site. The model site is characterised by the third stage of recreation digression and requires management of recreational pressure.

Model site 2 (MS2) is situated in the National Park Hetmanskyi, in a pine forest near Kam'yanka and Klymentove villages, in an area called 'Lytovskyi Bir. The vegetation cover undergoes low 
or moderate anthropogenic impact in the form of sanitary selective cuttings. We characterised this site as medium transformed. Oak-pine and maple-linden-oak woodlands near Kam'yanka are little disturbed by people, with diseased trees; the crown closure is approximately $20 \%$. The understory and shrub layers are typical for the habitat; 5-20\% of trees have insignificant damages. The grassy layer includes meadow grasses (5-10\%), not typical for this type of the forest. The forest floor is little disturbed. The area of paths is not large (up to $10-20 \%$ of the model site). In July-August, the recreational pressure increases due to a high number of visitors; but by this time, the breeding season of most of the birds has already finished. The site has the second level of recreational digression.

Model site 3 (MS3) is situated far from settlements, on the eastern bedrock bank of the Psel River in the site Vakalivshchyna and is represented by an oak forest mixed with maple and linden trees. The indicated territory has a low level of transformation and was chosen as a control area for breeding ecology monitoring of hollow-nesting birds. The crown canopy closure is approximately $85 \%$ (Table 1 ), and the share of damaged trees does not exceed $10 \%$ of their total abundance. The understory and shrub layers are typical for the habitat, without traits of noticeable damage. The grassy cover is mainly undisturbed and typical for the forest type. In some areas, excessive development of forest herbs is observed due to the fallout of overmature trees. The forest floor is undisturbed and thick. The recreational coefficient of the site was determined by the area of forest paths comprising $5 \%$. MS1 is characterised by the first level of recreational digression.

Model site 4 (MS4) lies in the parks of Kharkiv City. It is a predominantly natural upland oak grove with a small part of planted species, located in the watershed of the rivers Lopan and Kharkiv. This area is subject to significant anthropogenic pressure and has a high level of transformation. Its crown closure is approximately $60 \%$. Species of the forest edge, meadow, riparian-aquatic and ruderal plants are also recorded. There is an extended network of forest paths and roads, which people use for jogging. Increasing recreation pressure leads to the expansion of open glades and increasing density of paths. The maple Acer negundo forms dense thickets at the forest edge; in some places, garbage dumps are scattered. The closer to the forest border, the more ruderal species can be found. The site has the fourth and fifth levels of recreational digression.

A total of 75 nests of the great tits with 384 nestlings were inspected (Table 1). Of these, 62 nestlings $(n=12)$ were in the parks of Kharkiv City, $132(\mathrm{n}=26)$ in the National Park Homilshanski Lisy, $57(\mathrm{n}=11)$ in the site Vakalivshchyna and $133(\mathrm{n}=$ 26) were in the National Park Hetmanskyi. The nestling diet was investigated in the first half of the day by applying neck ligatures to 4-12-day-old chicks (Mal'chevskij, Kadochnikov, 1953). Fodder samples were taken from 3 to 5 times a season at each model plot. The research was conducted from 10 May to 30 June in the first half of the day; 271 food pellets were collected, and 325 food items, mostly arthropods, were studied. Of these, 43 food pellets were from the parks of Kharkiv City, 94 from the National Park Homilshanski Lisy, 40 from the site Vakalivshchyna and 94 were from the National Park Hetmanskyi. The forage samples were fixed in a 70\% solution of ethanol, and the arthropods were further identified in the laboratory. All the invertebrates were identified using standard methods to species, genus or family (in case of significant damage) by Associate Professor Viktor Gramma, $\mathrm{PhD}$.

To assess the width of the ecological niche of the great tit in the autumn-winter period, we used the traditional method (random multi-stage registration of foraging activity), in which the species of the tree, the altitude zone, the location of the bird and its location on the tree are recorded. The ratio of various postures that the great tit takes when searching for and acquiring food was investigated. Researchers distinguish a different number and variety of postures. Most often, 'hanging' back down and upside down postures are reported (Rezanov, 1999; Cramp et al., 1993).

Statistical treatment of the data was performed in the program Microsoft Excel. Similarity coefficients in the species composition of invertebrates found in the diet in different sites were calculated using the formulas of Jaccard (1901): $\mathrm{C}_{j}=j /(a+b-j)$ and Sorensen (1948): $\mathrm{C}_{s}=2 j /(a+b)$, where $j$ is the number of invertebrate species found in both groups, $a$ the number of species in the first group and $b$ is the number of species in the second group. These coefficients had values from 0 (no similarity between compared parameters) to 1 (complete similarity). The Stugren-Radulescu coefficient (1961) was calculated by the formula: $\mathrm{Pst}=(\mathrm{X}+\mathrm{Y}-\mathrm{Z}) /(\mathrm{X}+\mathrm{Y}+\mathrm{Z})$, where $\mathrm{X}$ is the number of species that occur on the first site, but are absent on the second; $\mathrm{Y}$ is the number of species that occur on the second site, but are absent on the first and $\mathrm{Z}$ is the number of species common on the both sites. These coefficients had values from -1 to 1 (in the range from -1 to 0 points to similarity, but within the range of $0-1$ to the difference of territories).

\section{Results}

The study showed that insectivorous birds play an important role in biological control of arthropod pest populations. In 2013-2016, in the diet of the great tit chicks, 325 food objects (invertebrates) were identified, which belong to 47 taxa from the phyla Arthropoda (99.1\%) and Mollusca (0.9\%) (Table 2). The phylum Arthropoda is represented by the following classes: Insecta 72.4\%, Arachnida - 21.7\%, Malacostraca and Myriapoda - 0.3\% each and Diplopoda - 0 9\%. The largest class Insecta includes 14 orders and 27 families. Representatives of the orders Lepidoptera (seven families, 35.9\%), Hymenoptera (two families, $21.0 \%$ ), Diptera (seven families, $2.7 \%$ ), Coleoptera (four families, $1.8 \%$ ), Heteroptera (two families, $0.6 \%$ ), Odonata, Blattoptera, Orthoptera, Neuroptera and Raphidioptera (one family, $0.3 \%$ each) and Dermaptera, Trichoptera, Psocoptera and Homoptera (one family, $0.3 \%$ each) were among them (Fig. 2).

The great tit connections as a heterotrophic nucleus of the determinant consortium are quite wide. Analysis of great tit chicks' diet showed that the basic trophic group for them is the first-order consumers (20 species, 42.6\%) (Fig. 3A). Representatives of the families Nitidulidae, Chrysomelidae, Curculionidae and Byturidae from the order Coleoptera (subphylum Hexapoda) belong to them. The identified insects of Psocoptera, Hymenoptera (Apoidea) and Hopoptera orders can be attributed to phytophages. Lepidopteran species from the families Tortricidae, Nymphalidae, Noctuidae, Geometridae, Lasiocampidae, Pieridae and Bombycidae of Macrolepidopteran clade (Rhopalocera) prevailed in the diet. Amber snails (Succinea sp.) from the family Succineidae (informal group Pulmonata, class Gastropoda, phylum Mollusca) formed only a small share of chicks' food. 
Table 2. List of the trophic items in the diet of the great tit in transformed forest ecosystems of northeastern Ukraine.

\begin{tabular}{|c|c|c|c|c|c|c|c|c|c|}
\hline \multicolumn{3}{|l|}{ Taxon name } & \multirow{2}{*}{$\begin{array}{l}\text { Trophic } \\
\text { group }\end{array}$} & \multirow{2}{*}{ MS1 } & \multirow{2}{*}{ MS2 } & \multirow{2}{*}{ MS3 } & \multirow{2}{*}{ MS4 } & \multirow{2}{*}{ Total } & \multirow{2}{*}{ Notes } \\
\hline Order & Family & Species & & & & & & & \\
\hline & & Insecta spp. & $\mathrm{ph}$ & & 9 larv. & & $\begin{array}{c}17 \\
\text { larv. }\end{array}$ & 26 & larv. \\
\hline Odonata & Libellulidae & Libellula fulva (Müller, 1764) & $\mathrm{z}$ & & 1 & & & 1 & imag. \\
\hline Blattoptera & Blattellidae & $\begin{array}{l}\text { Ectobius lapponicus } \\
\text { (Linnaeus, 1758) }\end{array}$ & $\mathrm{m}$ & 1 & & & & 1 & $-\ll-$ \\
\hline Orthoptera & Tettigoniidae & Tettigoniidae sp. & $\mathrm{m}$ & 1 larv. & & & & 1 & larv. \\
\hline Dermaptera & & Dermaptera sp. & $\mathrm{m}$ & 1 larv. & & & & 1 & $-\ll-$ \\
\hline \multirow[t]{2}{*}{ Hemiptera } & Miridae & $\begin{array}{l}\text { Myrmecophyes alboornatus } \\
\text { (Stål, 1858) }\end{array}$ & $\mathrm{m}$ & 1 & & & & 1 & imag. \\
\hline & Aphylidae & Aphylidae sp. & $\mathrm{m}$ & 1 & & & & 1 & $-\ll-$ \\
\hline \multirow[t]{5}{*}{ Coleoptera } & & Coleoptera sp. & $\mathrm{ph}$ & & 1 larv. & 1 larv. & & 2 & larv. \\
\hline & Nitidulidae & Meligethes sp. & $\mathrm{ph}$ & & & 1 & & 1 & imag. \\
\hline & Chrysomelidae & Chrysomelidae sp. & $\mathrm{ph}$ & & & 1 larv. & & 1 & larv. \\
\hline & Curculionidae & Curculionidae sp. & $\mathrm{ph}$ & 1 & & & & 1 & imag. \\
\hline & Byturidae & $\begin{array}{l}\text { Byturus ochraceus (Scriba, } \\
1790 \text { ) }\end{array}$ & $\mathrm{ph}$ & & & 1 & & 1 & $-\ll-$ \\
\hline Neuroptera & Chrysopidae & Chrysopa sp. & $\mathrm{z}$ & 1 larv. & & & & 1 & larv. \\
\hline \multirow[t]{5}{*}{ Hymenoptera } & Formicidae & Lasius alienus (Foerster, 1850) & $\mathrm{z}$ & 7 & & 13 & & 20 & imag. \\
\hline & & Lasius sp. & $\mathrm{z}$ & & & & 1 & 1 & $-\ll-$ \\
\hline & & Myrmica sp. & $\mathrm{z}$ & & & 1 & & 1 & $-\ll-$ \\
\hline & Tenthredinidae & Tenthredinidae sp. & $\mathrm{z}$ & & $\begin{array}{l}1,38 \\
\text { larv. }\end{array}$ & 1, 7 larv. & 1 larv. & 48 & $\begin{array}{c}2 \text { imag. } \\
+46 \\
\text { larv. }\end{array}$ \\
\hline & Apoidea & Apoidea sp. & ph & 1 & & & & 1 & imag. \\
\hline Raphidioptera & Raphidiidae & $\begin{array}{l}\text { Dichrostigma flavipes (Stein, } \\
1863 \text { ) }\end{array}$ & $\mathrm{z}$ & 1 & & & & 1 & $-\ll-$ \\
\hline Trichoptera & & Trichoptera sp. & $\mathrm{z}$ & 1 & & & & 1 & $-\ll-$ \\
\hline \multirow[t]{8}{*}{ Lepidoptera } & & Lepidoptera sp. & ph & $\begin{array}{c}5,1 \\
\text { pupae, } \\
2 \text { larv. }\end{array}$ & $\begin{array}{c}3,2 \\
\text { pupae, } \\
6 \text { larv. }\end{array}$ & & & 19 & $\begin{array}{c}8 \text { imag. } \\
+3 \\
\text { pupae }+ \\
8 \text { larv. }\end{array}$ \\
\hline & Tortricidae & Tortricidae sp. & $\mathrm{ph}$ & 1 & & 19 & & 20 & imag. \\
\hline & Nymphalidae & Nymphalidae sp. & $\mathrm{ph}$ & 1 larv. & & & & 1 & larv. \\
\hline & Noctuidae & Noctuidae sp. & $\mathrm{ph}$ & $\begin{array}{c}7,1 \\
\text { pupae, } \\
10 \text { larv. }\end{array}$ & $\begin{array}{c}7,3 \\
\text { pupae, } \\
27 \text { larv. }\end{array}$ & 3 & $\begin{array}{c}1,1 \\
\text { larv. }\end{array}$ & 60 & $\begin{array}{c}18 \\
\text { imag. }+ \\
4 \text { pupae } \\
+38 \\
\text { larv. }\end{array}$ \\
\hline & Geometridae & Geometridae sp. & $\mathrm{ph}$ & $\begin{array}{l}2,1 \\
\text { larv. }\end{array}$ & 1 larv. & & & 4 & $\begin{array}{l}2 \text { imag. } \\
+2 \text { larv. }\end{array}$ \\
\hline & Bombycidae & $\begin{array}{l}\text { Bombyx mori (Linnaeus, } \\
\text { 1758) }\end{array}$ & $\mathrm{ph}$ & 2 pupae & & & & 2 & pupae \\
\hline & Lasiocampidae & Lasiocampidae sp. & $\mathrm{ph}$ & $\begin{array}{c}1,1 \\
\text { pupae }\end{array}$ & $\begin{array}{c}7,3 \\
\text { pupae }\end{array}$ & 1 larv. & & 13 & $\begin{array}{c}8 \text { imag. } \\
+4 \\
\text { pupae }+ \\
1 \text { larv. }\end{array}$ \\
\hline & Pieridae & Pieridae sp. & $\mathrm{ph}$ & & 1 larv. & & & 1 & larv \\
\hline Diurna & & Rhopalocera sp. & $\mathrm{ph}$ & 1 & & & & 1 & imag. \\
\hline Psocoptera & & Psocoptera sp. & $\mathrm{ph}$ & & & 1 & & 1 & $-\ll-$ \\
\hline
\end{tabular}

Notes: Trophic groups of the mesofauna: $\mathrm{ph}$ - phytophages; $\mathrm{z}$ - zoophages; $\mathrm{m}$ - mixophages; $\mathrm{s}$ - saprophages; $\mathrm{n}$ - necrophages; pr - parasites; MS1-MS4 - model sites described in the section 'Materials and Methods'; imag. - imagoes; larv. - larvae; juv. - immature specimen(s). For taxa without symbols, the imago stage is given. 
Table 2. Continued

\begin{tabular}{|c|c|c|c|c|c|c|c|c|c|}
\hline \multicolumn{3}{|l|}{ Taxon name } & \multirow{2}{*}{$\begin{array}{l}\text { Trophic } \\
\text { group }\end{array}$} & \multirow{2}{*}{ MS1 } & \multirow{2}{*}{ MS2 } & \multirow{2}{*}{ MS3 } & \multirow{2}{*}{ MS4 } & \multirow[b]{2}{*}{ Total } & \multirow{2}{*}{ Notes } \\
\hline Order & Family & Species & & & & & & & \\
\hline \multirow[t]{7}{*}{ Diptera } & Tipulidae & Tipula sp. & $\mathrm{s}$ & & 1 & & & 1 & $-\ll-$ \\
\hline & Chironomidae & Chironomidae sp. & $\mathrm{s}$ & 2 & & & 1 & 3 & $-\ll-$ \\
\hline & Culicidae & Culicidae sp. & $\mathrm{s}$ & 1 & & & & 1 & $-\ll-$ \\
\hline & Tabanidae & $\begin{array}{l}\text { Tabanus bovinus Linnaeus, } \\
1758\end{array}$ & $\mathrm{~s}$ & & 1 & & & 1 & $-\ll-$ \\
\hline & Asilidae & Asilidae sp. & $\mathrm{z}$ & 1 & & & & 1 & $-\ll-$ \\
\hline & Muscidae & Muscidae sp. & $\mathrm{s}$ & & 1 & & & 1 & $-\ll-$ \\
\hline & Sarcophagidae & Sarcophagidae sp. & $\mathrm{n}$ & 1 larv. & & & & 1 & larv. \\
\hline \multirow[t]{2}{*}{ Homoptera } & & Homoptera sp. & $\mathrm{ph}$ & 1 larv. & & & & 1 & $-\ll-$ \\
\hline & & Arachnida spp. & $\mathrm{z}$ & & $\begin{array}{l}24,1 \\
\text { juv. }\end{array}$ & & & 25 & $\begin{array}{c}24+1 \\
\text { juv. }\end{array}$ \\
\hline Araneae & & Araneae sp. & $\mathrm{z}$ & $\begin{array}{l}23,4 \\
\text { juv. }\end{array}$ & & $\begin{array}{c}12,1 \\
\text { nymph, } \\
4 \text { juv. }\end{array}$ & 3 & 47 & $\begin{array}{c}38 \\
\text { imag. } \\
+1 \\
\text { nymph } \\
+8 \text { juv. }\end{array}$ \\
\hline Acari & & Acari sp. & pr & 1 & & & & 1 & imag. \\
\hline Isopoda & Oniscidae & Oniscidae sp. & $\mathrm{s}$ & 1 & & & & 1 & $-\ll-$ \\
\hline Myriapoda & & Myriapoda sp. & $\mathrm{s}$ & 1 & & & & 1 & $-\ll-$ \\
\hline Diplopoda & & Diplopoda sp. & $\mathrm{s}$ & & & 1 & & 1 & $-\ll-$ \\
\hline \multirow[t]{2}{*}{ Julida } & Julidae & Julus sp. & s & 1 larv. & & 1 & & 2 & $\begin{array}{l}1 \text { imag. } \\
+1 \text { larv. }\end{array}$ \\
\hline & & Mollusca sp. & ph & 1 & 1 & & & 2 & imag. \\
\hline Pulmonata & Succineidae & Succinea sp. & $\mathrm{Ph}$ & & 1 & & & 1 & $-\ll-$ \\
\hline \multicolumn{4}{|l|}{ Total } & & & & & 325 & \\
\hline
\end{tabular}

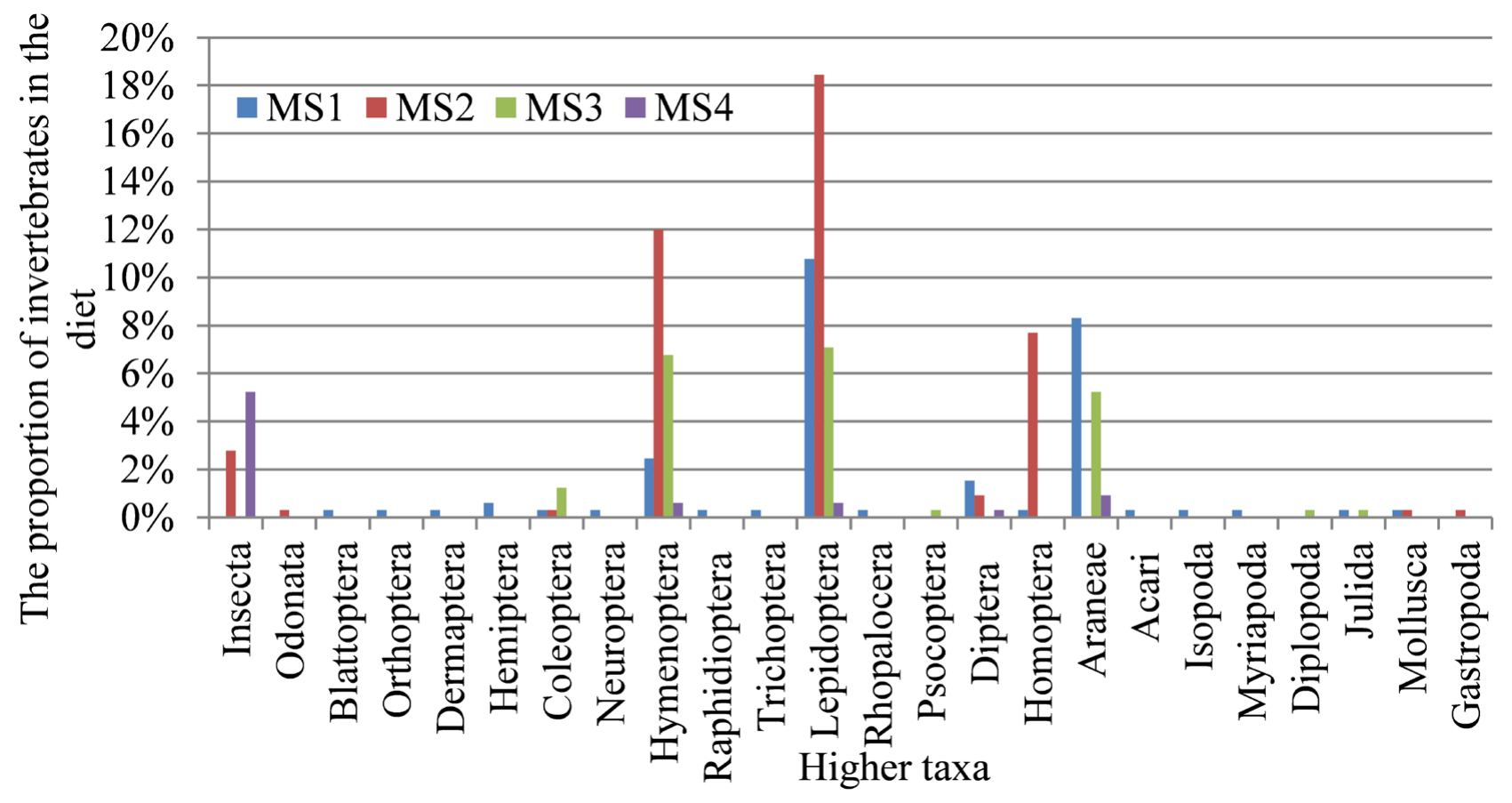

Fig. 2. The ratio of invertebrates in the Parus major chicks' diet. 
$2.13 \% .13 \%$

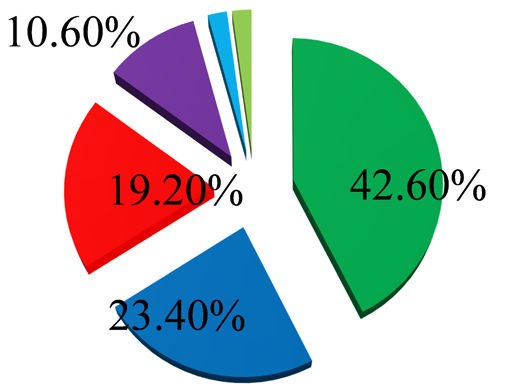

phytophages

- zoophages

saprophages

mixophages

necrophages

parasites

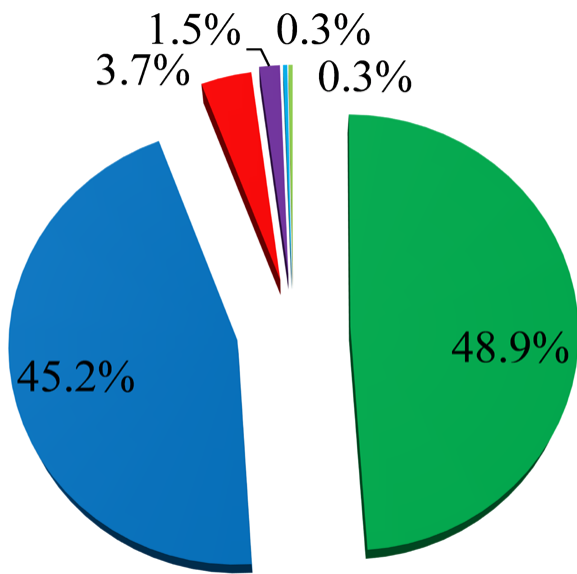

B

Fig. 3. Distribution of the great tit nestling diet per trophic group: A - percentage of the total number of species; B - percentage of the total number of registered food items.

Table 3. Invertebrate similarity in the big tit diet in model sites.

\begin{tabular}{|c|c|c|c|c|}
\hline \multirow{2}{*}{ Pair of model sites } & \multirow{2}{*}{ Number of invertebrates found in both sites } & \multicolumn{3}{|c|}{ Similarity index } \\
\cline { 3 - 6 } & & Stugren-Radulescu & Jaccard & Sorensen \\
\hline MS1-MS2 & 4 & 0.8 & 0.1 & 0.2 \\
\hline MS1-MS3 & 6 & 0.7 & 0.2 & 0.3 \\
\hline MS1-MS4 & 3 & 0.8 & 0.1 & 0.2 \\
\hline MS2-MS3 & 4 & 0.7 & 0.2 & 0.3 \\
\hline MS2-MS4 & 3 & 0.7 & 0.2 & 0.3 \\
\hline MS3-MS4 & 3 & 0.6 & 0.2 & 0.3 \\
\hline
\end{tabular}

In the great tit diet, zoophages (11 species, $23.4 \%)$ from the subphylum Hexapoda (Fig. 3A) are represented by Odonata (Libellulidae), Neuroptera (Chrysopidae), Hymenoptera (Formicidae and Tenthredinidae), Raphidioptera (Raphidiidae), and Trichoptera and Diptera (Asilidae).

From a separate important group of mixophages (five species, 10.6\%) (Fig. 3A), representatives from the Blattodea (Blattellidae), Orthoptera (Tettigoniidae), Dermaptera and Heteroptera (Miridae and Aphylidae) groups were found in the great tit ration.

Analysis of the diet of great tit chicks revealed a complex of species of the detritivores unit of birds' consortium. Among detritivores, saprophages, necrophages and parasites are identified depending on trophic links. Saprophages are consumers of dead organic matter of plant origin. The saprophages (nine species, 19.2\%) (Fig. 3A) in the diet are the representatives of the order Diptera from the families Tipulidae, Chironomidae, $\mathrm{Cu}$ licidae, Muscidae and Tabanidae of the subphylum Hexapoda. Representatives of the family Oniscidae (subtype Crustacea, class Malacostraca, order Isopoda) can be attributed to saprophages. In the food of the great tit chicks, a representative of the saprophages, in particular, Julus sp. from subphylum Myriapoda, was found.

Necrophages or scavengers are those feeding on dead animals. Necrophages (one species, 2.1\%) (Fig. 3A) in the feeding objects of great tit chicks include grey flies from the order Diptera. Representatives of the grey meat flies and Fanniidae families are the first to arrive at the smell of dead animals; they lay eggs and within 2 weeks, a new generation of flies develops.

A representative of parasites (one species, 2.1\%) (Fig. 3A) from the subclass Acari was found in the diet of the great tit.

Phytophages (159 objects) also predominated in the feeding of great tit chicks; zoophages (147 objects) were subdominant. Significantly fewer saprophages (12 objects), mixophages (five objects), and necrophages and parasites (one object each) were found (Fig. 3B). In different territories, unequal amount of food objects of great tit chicks were taken. Thus, phytophages prevailed in MS2 both in the number of collected objects (51.5\%; $\mathrm{n}$ $=72$ ) and in the number of species (nine species; 60.0\%). In MS3, the number of objects was dominated by zoophages $(56.5 \%$; $n$ = 39), but the number of species of birds that gathered in this area was greater among phytophages (eight species; $17.0 \%)$. In MS1, the majority of food objects $(44.0 \%$; $n=40)$ were represented by phytophages, as well as by the number of species (12 species; $40.0 \%)$. In MS4, birds by the number of objects (76.0\%; $\mathrm{n}=19$ ) (Fig. 4B) were more likely to gather representatives of phytophages and by the number of species gather representatives of zoophages (3 species; 50.0\%) (Fig. 4A).

In MS3, the great tits feeding on household soap and toilet soap, as well as germ parts of corn kernels (Zea mays Mill.) of 


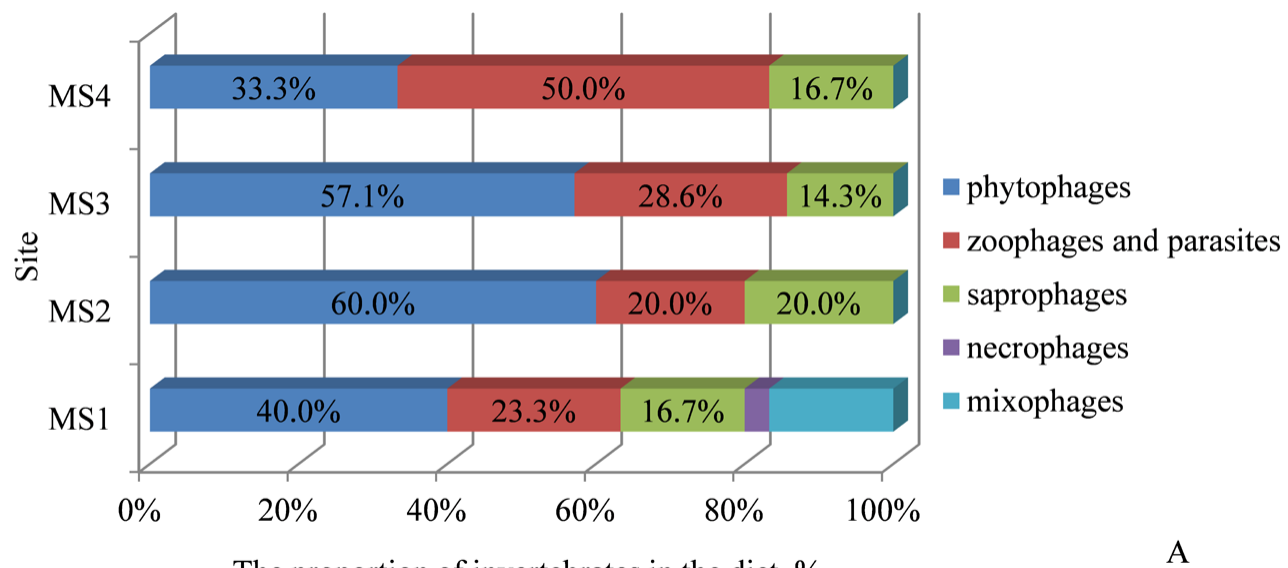

The proportion of invertebrates in the diet, $\%$

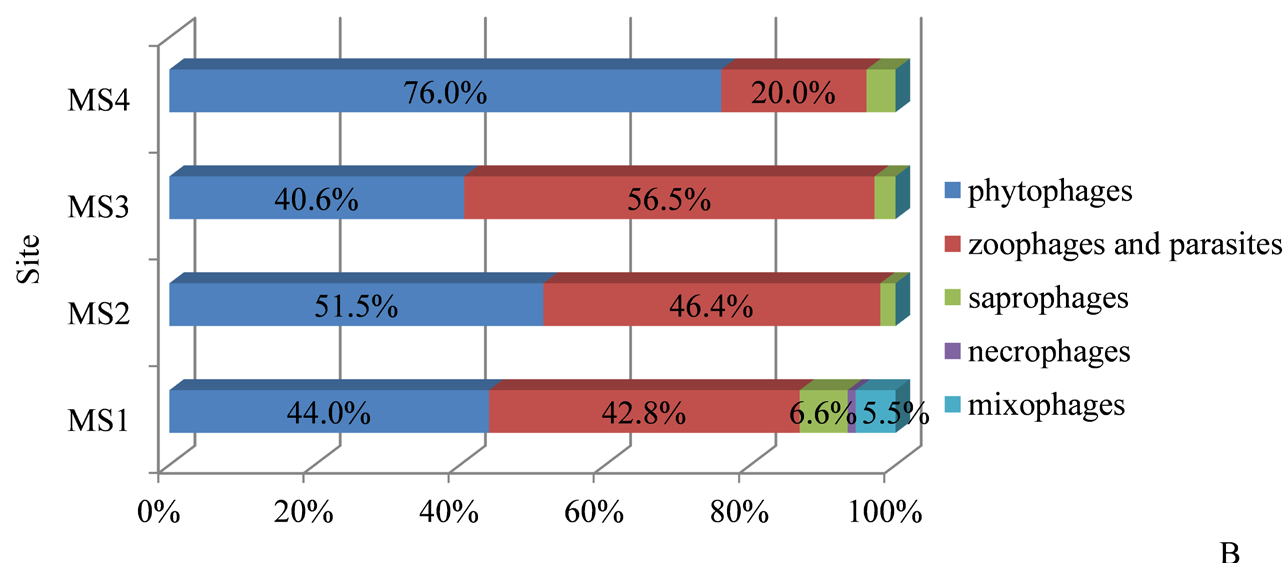

The proportion of invertebrates in the diet, $\%$

Fig. 4. Distrubution of trophic groups of the great tit in model sites: A - proportion of the total number of species, B - proportion of the total number of objects.

sugar varieties is known from literary sources (Knish, 2014). The great tit pecking of soap was reported from Moscow region (Prokhorov, 2010).

An analysis of the similarity of invertebrate species that are part of the feed of great tit chicks showed that MS1 and MS3 were the most similar in this respect (Table 3), where six common taxa were found for these territories (Arthropoda: Insecta: Hymenoptera: Formicidae: Lasius alienus, Lepidoptera: Tortricidae, Noctuidae, Lasiocampidae, Arachnida: Araneae, Diplopoda: Julida: Julidae: Julus sp.).

In MS1, in spring, great tits gathered food in the crowns of deciduous trees (Norway maple, common birch, common oak [Quercus robur Sol.], ash), mainly in the lower tier, in the leaves of bushes (elder, mountain ash, Prunus L.) and underbrush. In $\mathrm{MS} 2$, in the fall and winter, they gathered food on conifers ( $P i$ nus silvestris L.), inspect the undergrowth and undergrowth. In search of food, they moved along branches, often upside down. Rarely, they sought out loose seeds and fruits of plants on the ground. In winter, they fed on spiders and larvae hiding under the bark and also collected forage objects in the snow. In the fall and winter, they formed mixed flocks with blue tits, crested tit, brown-headed tit (Poecile montanus Conrad von Baldenstein) and wood nuthatch (Sitta europaea L.) to search for food. They did not make their stocks for winter, but fed at the expense of other species of flocks.

\section{Discussion}

In the structure of biogeocenosis, the great tit is considered as a heterotrophic core of a determinant consortium. As a zoo- and partially phytophage in a forest biogeocenosis, it belongs to the consumer nucleus of the second order and forms a complex system based on trophic and topical interactions.

Consumers of second, third and higher orders in the consortium of the great tit include representatives of the order Araneae, which are also often found in the diet of the beefy flycatcher (Ficedula albicollis Temm.) (Lezhenina et al., 2009; Polchaninova, Prisada, 1994) and spotted flycatcher (Muscicapa striata) (Chaplygina et al., 2018), blue tit (Parus caeruleus L.) (Berezantseva, 1998; Yuzyk, Chaplygina, 2016), robin (Erithacus rubecula L.) (Chaplygina et al., 2016), song thrush (Chaplygina et al., 2019) and sparrow (Passer monthanus L.) (Yuzyk, Chaplygina, 2015). 
The massiveness of the ants of the genus Lasius, flies from the flesh flies family (Sarcophagidae) and tachinids (Tachinidae), is compensated by the large number of other zoophages of higher taxa, such as the birds (Aves), which prevent outbreaks of their numbers. In addition, the aforementioned insects are a reliable source of food for great tits and other passerines, such as the robin (Chaplygina et al., 2016), collared flycatcher (Chaplygina et al., 2015), field sparrow (Yuzyk, Chaplygina, 2015) and blue tit (Yuzyk, Chaplygina, 2016).

The relationship between the degree of ecosystem transformation and the diet of chicks has been revealed. Thus, it was noted that the largest species diversity of invertebrates in the feed samples of great tit chicks was in areas with medium (MS1 and MS2) and low degree of transformation (MS3). And then, with an increase in the degree of transformation of the territory, the species diversity of invertebrates in the diet of great tit chicks decreased significantly (MS4 - six species of invertebrates). The largest number of common invertebrate species in the feed samples of great tit chicks was also found in areas with medium (MS1 and MS2) and low degree of transformation (MS3).

\section{Conclusion}

The diet of great tit chicks in the forest ecosystems of northeastern Ukraine was first studied using model plots with varying degrees of anthropogenic transformation. The classification of invertebrates (objects of the diet of great tit chicks) by trophic groups has been carried out.

Great tits are insectivorous polyphages. The basis of the diet of large tits is formed by phytophagous insects. The feeding objects of these birds in areas with different levels of transformation have a low degree of similarity, which indicates a slight selectivity and ability of the birds to switch to common types of food and regulate the number of phytophagous insects in forests, gardens and parks, and also explains their widespread distribution in all study areas. The feeding of great tits by all available arthropods within nesting areas, probably, is an adaptation that evolved due to their year-round stay in the study area.

For the first time, an analysis of the feeding behaviour of the great tit in the forest ecosystems of northeastern Ukraine was performed.

\section{References}

Amrhein, V. (2013). Wild bird feeding (probably) affects avian urban ecology. Avian Urban Ecology, 29-38. DOI: 1093/acprof:oso bl/9780199661572.003.0003.

Banbura, J., Lambrechts, M.M., Blondel, J., Perret, P. \& Cartan-Son M. (1999). Food handling time of Blue Tit chicks: constraints and adaptation to different prey types. Journal of Avian Biology, 30(3), 263-270. DOI: $10.2307 / 3677352$.

Barba, E. \& Gildelgado, Ja. (1990). Seasonal-variation in nestling diet of the great tit Parus major in Orange Groves in Eastern Spain. Ornis Scandinavica, 21(4), 296-298. DOI: 10.2307/3676396.

Berezantseva, M.S. (1998). Feeding of nestlings blue tits Parus caeruleus in the forest-steppe oakgrove «Les na Vorskle» (in Russian). The Russian Journal of Ornithology, 31, 10-16.

Blondel, J., Dervieux, A., Maistre, M. \& Perret P. (1991). Feeding ecology and life-history variation of the blue tit in mediterranean deciduous and sclerophyllous habitats. Oecologia, 88(1), 9-14. DOI: 10.1007/bf00328397.

Bridgeland, W.T., Beier, P., Kolb, Th. \& Whitham Th.G. (2010). A conditional trophic cascade: birds benefit faster growing trees with strong links between predators and plants. Ecology, 91(1), 73-84. DOI: 10.1890/081821.1.
Brooks, D.R., Storkey, J., Clark, S.J., Firbank, L.G., Petit, S. \& Woiwodlan P. (2012). Trophic links between functional groups of arable plants and beetles are stable at a national scale. Journal of Animal Ecology, 81, 4-13. DOI:1 0.1111/j.1365-2656.2011.01897.x

Chaplygina, A.B., Gramma, V.N., Bondarecz, D.I. \& Savynska N.O. (2015) Arthropods in trophic-cenosis structure of collared flycatcher consortium in conditions of forest ecosystems of North-Eastern Ukraine (in Ukrainian). Bulletin of Dnipropetrovsk University. Biology, Ecology, 23(1), 74-85.

Chaplygina, A. \& Pakhomov O. (2020). Trophic links of the blackbird (Turdus merula Linnaeusm 1758) in transformed forest ecosystems of northeastern Ukraine. Ekológia (Bratislava), 39(4), 333-342. DOI: 10.2478/ eko-2020-0027.

Chaplygina, A.B., Pakhomov, O.Y. \& Brygadyrenko, V.V. (2019). Trophic links of the song thrush (Turdus philomelos) in transformed forest ecosystems of North-Eastern Ukraine. Biosystems Diversity, 27 (1), 51-55. DOI: $10.15421 / 011908$.

Chaplygina, A.B., Savynska, N.O. \& Brygadyrenko V.V. (2018). Trophic links of the spotted flycatcher, Muscicapa striata, in transformed forest ecosystems of North-Eastern Ukraine. Baltic Forestry, 24(2), 304-312. DOI: $10.15421 / 012013$

Chaplygina, A.B., Yuzyk, D.I. \& Savynska N.O. (2016). The robin, Erithacus rubecula (Passeriformes, Turdidae) as a component autotrophic consortia of forest cenoses, Northeast Ukraine. Vestnik Zoologii, 50(4), 369378. DOI: 10.1515/vzoo-2016-0043.

Cholewa, M. \& Wesolowski T. (2011). Nestling food of European hole-nesting passerines: do we know enough to test the adaptive hypotheses on breeding seasons? Acta Ornithologica, 46(2), 105-116.

Cramp, S., Perrins, C.M. \& Brooks D.J. (1993). Handbook of the Birds of Europe, the Middle East and North Africa. The Birds of the Western Palearctic. Oxford: Oxford University Press.

Garcia-Navas, V. \& Sanz J.J. (2010). Flexibility in the Foraging Behavior of Blue Tits in Response to Short-Term Manipulations of Brood Size. Ethology, 116(8), 744-754. DOI: 10.1111/j.1439-0310.2010.01788.x.

Garcia-Navas, V. \& Sanz J.J. (2011). The importance of a main dish: nestling diet and foraging behaviour in Mediterranean blue tits in relation to prey phenology. Oecologia, 165(3), 639-649. DOI: 10.1007/s00442010-1858-z.

Gensiruk, S.A. (2002). Forests of Ukraine (in Ukrainian). L'viv: Vy`d-vo Nauk. tov. im. Shevchenka, UkrDLTU.

Grzędzicka, E. (2018). Habitat and diet variability of two coexisting tit species in central European forests. Bird Study, 65(1), 52-61. DOI: 10.1080/00063657.2018.1443054.

Hanzelka, J. \& Reif J. (2015). Responses to the black locust (Robinia pseudoacacia) invasion differ between habitat specialists and generalists in central European forest birds. Journal of Ornithology, 156, 1015-1024. DOI: $10.1007 /$ s10336-015-1231-4

Jaccard, P. (1901). Distribution de la flore alpine dans le Bassin des Dranses et dans quelques regions voisines. Bull. Soc. Vaudoise Sci. Natur., 37(140) 241-272. DOI: $10.5169 /$ seals-266440.

Knish, N.P. (2014). About consumption by big tits of unusual food - soap and corn kelnels (in Russian). The Russian Journal of Ornithology, 23(970), 512-513.

Korňan, M. \& Adamík P. (2017). Tree species preferences of foraging insectivorous birds in a primeval mountain mixed forest: Implications for management. Scandinavian Journal of Forest Research, 32, 1-8. DOI: 10 1080/02827581.2017.1299211.

Kuwae, T., Miyoshi, E., Hosokawa, Sh., Ichimi, K., Hosoya, J., Amano, T., Moriya, T., Kondoh, M., Ydenberg, R.C. \& Elner R.W. (2012). Variable and complex food web structures revealed by exploring missing trophic links between birds and biofilm. Ecology Letters, 15, 347-356. DOI 10.1111/j.1461-0248.2012.01744.x.

Lezhenina, I.P., Gramma, V.N., Savinskaya, N.A. \& Chaplyigina A.B. (2009). The arthropods in nests of collared flycatcher in the upland oak forest (Kharkiv region) (in Russian). Scientific Statements of Belgorod State University. A series „Natural Sciences“, 3(58), Part 8, 95-100.

Mal'chevskij, A.S. \& Kadochnikov A.S. (1953). Methods of in vivo study of feeding of nesting nestlings of insectivorous birds (in Russian). Zoological Journal, 32(2), 227-282.

Polchaninova, N.Yu. \& Prisada I.A. (1994). The spiders in the diet of nestlings collared flycatcher in upland oak forests of the Kharkiv region (in Russian). Kharkov Entomological Society Gazette, 2(1), 46-149. 
Prokhorov, V.G. (2010). Unusual feeding behavior of big tit Parus major (in Russian). The Russian Journal of Ornithology, 19(579), 1123.

Rezanov A.G. (1999). Methods of study and registration of bird activity feed (in Russian). Vertebrate animals and observing of them in nature (pp. 42-55).Moscow: Publishing Center «Academy».

Sorensen, T.A. (1948). A method of establishing groups of equal amplitude in plant sociology based on similarity of species content. Kongelige Danske Videnskabernes Selskab. Biol. Krifter, 5(4), 1-34.

Støstad, H.N. (2017). Foraging on human-derived foods by urban birds species. Bird Study, 64(2), 178-186. DOI:10.1080/00063657.2017.1311836.

Stugren, B. \& Radulescu M. (1961). Metode zoogeography: With special reference to land animals. New York: Reinhold.

Teichman, K.J., Nielsen, S.E. \& Roland J. (2013). Trophic cascades: linking ungulates to shrubdependent birds and butterflies. Journal of Animal Ecology, 82, 1288-1299. DOI:10.1111/1365-2656.12094.
Yuzyk, D.I. \& Chaplygina A.B. (2015). The consortial relations of the Tree Sparrow (Passer montanus) in conditions of the forest cenoses of Northeaste Ukraine (in Ukrainian). Berkut, 24(2), 142-147.

Yuzyk, D.I. \& Chaplygina A.B. (2016). Blue Tit (Parus caeruleus L.) in the system of consortia in the conditions of the forest ecosystems of NorthEastern Ukraine (in Ukrainian). In I.V. Skilsky \& A.V. Yuzyk (Eds.), Regional aspects of floristic and faunistic research: proceeding of the third international scientific and practical conference (13-14 May 2016, Putyla - Chernivtsi, Ukraine) (pp. 83-87). Ministry of Ecology and Natural Resources of Ukraine, Cheremosh National Park and Other. Chernivtsi: Druk Art. 